\title{
PHYTOPHAGY ON FOSSIL FERNS FROM ARGENTINA (PALO PINTADO FORMATION, LATE MIOCENE): A REVIEW OF THEIR FOSSIL RECORD AND ICHNOTAXONOMY
}

\author{
JUAN M. ROBLEDO \\ Centro de Ecología Aplicada del Litoral (CECOAL), CONICET, Ruta 5 km 2,5, Corrientes 3400, Argentina. \\ robledomanuel@rocketmail.com \\ LAURA C. SARZETTI \\ División de Icnología, Museo Argentino de Ciencias Naturales “Bernardino Rivadavia”, CONICET, \\ Av. Angel Gallardo 470, Capital Federal 1405, Buenos Aires, Argentina. Isarzetti@macn.gov.ar \\ LUISA M. ANZÓTEGUI \\ Centro de Ecología Aplicada del Litoral (CECOAL), CONICET, Ruta 5 km. 2,5, Corrientes 3400, Argentina. \\ luisaanzotegui@yahoo.com
}

\begin{abstract}
Evidence of insect-fern interactions are described for the first time from late Miocene strata of Salta Province, Argentina. Two ichnospecies are defined to include fossil traces of surface feeding and hole feeding, located between the secondary veins and adjacent with the primary vein of two species of fossil ferns, Blechnum serrulatiformis Anzótegui \& Horn and Thelypteris interrupta (Willd.) Iwatsuki. The first ichnospecies corresponding with surface feeding presents oblong traces and both ends are rounded; occupying the entire intercostal space. This type of phytophagy is found for the first time in the fossil record of ferns. The second ichnospecies is similar in shape and location to the previous ichnotaxon, except that all herbivorized tissues are absent. At last, a review of the fossil record of insect-fern associations is performed.
\end{abstract}

Key words: insect-fern interactions, fossil traces, surface feeding, hole feeding.

RESUMO - Descreve-se pela primeira vez evidência de interações inseto-samambaia no Mioceno superior da Província de Salta, Argentina. Duas icnoespecies são propostas para incluir rastros fósseis de alimentação superficial e alimentação em orifícios, localizadas entre as veias secundárias e adjacentes à veia primária em duas espécies de samambaias fósseis, Blechnum serrulatiformis Anzótegui \& Horn e Thelypteris interrupta (Willd.) Iwatsuki. A primeira espécie corresponde à alimentação superficial, apresenta rastros oblongos com ambos os extremos arredondados e ocupa todo o espaço intercostal. Este é o primeiro registro de alimentação superficial em samambaias fósseis. A segunda espécie similar na sua forma e localização ao icnotáxon previamente descrito, exceto que todas as camadas de tecido herbivorizado estão ausentes. Finalmente, uma revisão do registro fóssil das associações inseto-samambaia também é realizada.

Palavras-chave: interação inseto-samambaia, traços fósseis, alimentação superficial, alimentação em orifício.

\section{INTRODUCTION}

Ferns appeared in the Middle Devonian, about 390 Ma (Scheckler, 1974; Rothwell \& Stockey, 2008). Subsequently, they have diversified on all continents (Bancroft, 1932; Herbst, 1977; Rothwell \& Stockey, 1989; Van KonijnenburgVan Cittert, 1989; Tidwell \& Ash, 1994; Hill \& Jordan, 1998; Wang, 1999; Rößler, 2001), establishing three diversification events during the Carboniferous, the Permian-Jurassic and the Cretaceous (Rothwell, 1987; Tomescu et al., 2006; Schuettpelz \& Pryer, 2009).

Despite the ferns and insects occurred in the same past environments, fossil and even extant evidence of insect-fern associations are poorly documented (Table 1). Examples of insect damages on fossils is based on indirect evidence of coprolites that often occur within the rachises, stems and sporangia (Seward, 1923, 1924; Rothwell \& Scott, 1983; Scott \& Paterson, 1984; Scott et al., 1985; Rex \& Galtier, 1986; Labandeira \& Beall, 1990; Lesniskowska, 1990; Labandeira et al., 1997; Ash, 2000; Rößler, 2000; Labandeira \& Phillips, 2002; Kellogg \& Taylor, 2004; D’Rozario et al., 2011; Slater et al., 2012), and to a lesser extent damage inflicted on leaves (Webb, 1982; Hill, 1987; Ash, 1997; Labandeira, 2002b, McLoughlin et al., 2015). Fossil insect-plant interactions in Argentina are poorly documented. Césari et al. (2012) described coprolites in Cuyoxylon Pujana \& Césari, 2008 roots and stem San Ignacio Formation (Late Carboniferous-Early Permian) from, San Juan Province. Possible oviposition or hole feeding 
Table 1. Fossil record of insect-fern interactions.

\begin{tabular}{|c|c|c|c|c|c|}
\hline Interaction type & Part of plant & Evidence & Taxa & Age & Author \\
\hline Marginal excisions & Foliar lamina & Plant damage & Fern sp. indet. & middle Eocene & Labandeira (2002b) \\
\hline Marginal excisions & Foliar lamina & Plant damage & Filicalean fern sp. indet. & Late Cretaceous & $\begin{array}{l}\text { Labandeira et al. } \\
\text { (2002) }\end{array}$ \\
\hline Pith boring & Stem & Coprolites & Tempskya sp. (Polypodiales) & Cretaceous & $\begin{array}{l}\text { Scott \& Paterson } \\
\text { (1984) }\end{array}$ \\
\hline Root boring & Root & Coprolites & Tempskya sp. (Polypodiales) & Cretaceous & Seward (1923) \\
\hline Pith boring & Stem & Coprolites & Tempskya wyomingense (Polypodiales) & Early Cretaceous & $\begin{array}{l}\text { Tidwell \& Hebbert } \\
\text { (1992) }\end{array}$ \\
\hline Pith boring & Stem & Coprolites & Tempskya knowltoni (Polypodiales) & Early Cretaceous & Seward (1924) \\
\hline Marginal excisions & Foliar lamina & Plant damage & & & \\
\hline Hole feeding & Foliar lamina & Plant damage & Cladophlebis australis (Filicales) & Middle Jurassic & $\begin{array}{l}\text { McLoughlin et al. } \\
\text { (2015) }\end{array}$ \\
\hline Piercing and sucking & Foliar lamina & Plant damage & & & \\
\hline Hole feeding & Foliar lamina & Plant damage & Angiopteris blackii (Marattiales) & Middle Jurassic & Hill (1987) \\
\hline Pith boring & Petioles & Coprolites & Itopsidema vancleaveii (Filicales) & Late Triassic & Ash (2000) \\
\hline Skeletonizations & Foliar lamina & Plant damage & $\begin{array}{c}\text { Dictyophyllum nathorstii } \\
\text { (Gleicheniales) }\end{array}$ & Late Triassic & Feng et al. (2014) \\
\hline Marginal excisions & Foliar lamina & Plant damage & Cynepteris lasiophora (Filicales) & Late Triassic & Ash (1997) \\
\hline Galls or oviposition? & Foliar lamina & Plant damage & $\begin{array}{c}\text { Dictyophyllum bremerense } \\
\text { (Gleicheniales) }\end{array}$ & $\begin{array}{l}\text { Middle-Late } \\
\text { Triassic }\end{array}$ & Webb (1982) \\
\hline Pith boring & Petiole & Coprolites & Antarctipteris sp. (Gleicheniales) & Middle Triassic & $\begin{array}{l}\text { Kellogg \& Taylor } \\
\text { (2004) }\end{array}$ \\
\hline Pith boring & Stem & Coprolites & Psaronius housuoensis (Marattiales) & late Permian & $\begin{array}{l}\text { D’Rozario et al. } \\
\text { (2011) }\end{array}$ \\
\hline Palynophagy & Sporangium & Coprolites & Fern sp. indet. & middle Permian & Slater et al. (2012) \\
\hline Pith boring & Stem & Coprolites & Ankyropteris brongniartii (Filicales) & early Permian & Rößler (2000) \\
\hline Root boring & Root & Coprolites & Psaronius (Marattiales) & еагіу Permian & Roisler (2000) \\
\hline Pith boring & Stem & Coprolites & Psaronius (Marattiales) & Early & Labandeira \& \\
\hline Galling & Petioles & Plant damage & Psaronius (Marattiales) & Carboniferous & Phillips (2002) \\
\hline Root boring & Root & Coprolites & Psaronius sp. (Marattiales) & Late Carboniferous & $\begin{array}{l}\text { Labandeira et al. } \\
\text { (1997) }\end{array}$ \\
\hline Piercing and sucking & Rachis & Plant damage & Psaronius (Marattiales) & Late Carboniferous & $\begin{array}{l}\text { Labandeira \& } \\
\text { Phillips (1996a) }\end{array}$ \\
\hline Galling & Petioles & Plant damage & Psaronius chasei (Marattiales) & Late Carboniferous & $\begin{array}{l}\text { Labandeira \& } \\
\text { Phillips (1996b) }\end{array}$ \\
\hline Pith boring & Petiole & Coprolites & Psaronius chasei (Marattiales) & Late Carboniferous & $\begin{array}{l}\text { Lesnikowska } \\
\text { (1990) }\end{array}$ \\
\hline Pith boring & Stem & Coprolites & Psaronius sp. (Marattiales) & Late Carboniferous & $\begin{array}{c}\text { Labandeira \& Beall } \\
\text { (1990) }\end{array}$ \\
\hline Pith boring & Stem & Coprolites & Psaronius magnificus (Marattiales) & Late Carboniferous & $\begin{array}{l}\text { Rothwell \& Scott } \\
\text { (1983) }\end{array}$ \\
\hline Pith boring & Rachis & Coprolites & Zygopterid fern (Zygopteridales) & Early & Rex \& Galtier \\
\hline Pith boring & Rachis & Coprolites & Botryopteris (Ophioglossales) & Carboniferous & (1986) \\
\hline
\end{tabular}

have been reported by Cúneo (1987) in Ginkgoites Seward, 1919 leaves from Río Genoa Formation (Lower Permian) in Chubut. Recently, Gallego et al. (2014) described plant-insect associations in gymnosperms in the same formation. In $\mathrm{La}$ Golondrina Formation (Mid-Late Permian) from Santa Cruz Province, traces on the leaves of Glossopteris Brongniart, 1828 species were described by Cariglino \& Gutiérrez (2011). The fossil record of insect-plant interactions in angiosperm leaves is more abundant than Paleozoic and Mesozoic records in other host plants. These occurrences come from Chubut (Early Eocene) and Rio Negro (Middle Eocene) provinces (Wilf et al., 2005; Sarzetti et al., 2008, 2009; Sarzetti, 2010; Carvalho et al., 2013). More recently, Horn et al. (2011) documented insect-mediated damage from the Middle and Upper Miocene from Tucumán and Salta Provinces. Until now, the only record known about insect-fern interactions from Argentina, is the one described by Carvalho et al. (2013) in the Early Eocene flora from Laguna del Hunco, Chubut Province. The ichnotaxonomy of insect trace fossils on leaves was proposed originally by Vialov (1975), which was later used by other authors (Straus, 1977; Givulescu, 1984; Vasilenko, 2005, 2007a,b; Sarzetti et al., 2008, 2009). Most evidence of surface and hole-feeding damage on fossil leaves were described in the literature but without a formal ichnotaxonomic analysis (Ash, 1997; Zherikhin, 2002; Labandeira, 2002b; Labandeira et al., 2002, 2007; Banerji, 2004; Prevec et al., 2009; Srivastava \& Agnihotri, 2011). Givulescu (1984) described the ichnospecies Phagophytichnus gastropodinus in fossil angiosperm leaves and showed that some features would allow assignment to surface feeding. The only ichnogenus defined formally for surface feeding is 
Cephaloleichnites Wilf, Labandeira, Kress, Staines, Windsor, Allen \& Johnson, 2000, assigned as a combination of damage type made by different instars and included larval and adult feeding trails (Wilf et al., 2000). Hole feeding on fossil leaves were defined ichnotaxonomically by Vasilenko (2007a), but he described these traces as windows excisions.

Early studies on the Palo Pintado Formation were focused mostly on plant diversity and taxonomy. The fossil occurrence consists of different plant organs of angiosperms and ferns (leaves, fronds, fruits, woods, pollen and spores) (Herbst et al., 1987, 2000; Anzótegui, 1992, 1998; Lutz \& Martinez, 2007; Anzótegui \& Horn, 2011). Also, paleoenvironmental reconstructions were performed (Herbst et al., 1987; Galli et al., 2011) and recently trace fossils on leaves were described (Anzótegui et al., 2008; Horn et al., 2011).

The aims of this contribution are twofold. First, trace fossils attributed to phytophagous insects are documented on two species of ferns, Blechnum serrulatiformis (Blechnaceae), and Thelypteris interrupta (Thelypteridaceae) from Argentina. These new records are placed in a paleontological context that includes other similar insect traces on leaves. Second, two ichnospecies are established to include fossil traces of surface feeding and hole feeding.

\section{GEOLOGICALS ETTING}

The fossil impressions were collected from Palo Pintado Formation, at the central southern region of Salta Province, Argentina. The fossil sites are between these two coordinates $25^{\circ} 41^{\prime} 01^{\prime \prime} \mathrm{S}, 66^{\circ} 07^{\prime} 55^{\prime \prime} \mathrm{W}$ and 25 $40^{\prime} 59^{\prime \prime} \mathrm{S}, 66^{\circ} 05^{\prime} 49^{\prime \prime} \mathrm{W}$ (Galli et al., 2011), with an age constrained between 10.29 + 0.11 Ma (K/Ar) (Galli et al., 2008) and 5.27+ $0.28 \mathrm{Ma}$ (Coutand et al., 2006) at its upper section. This formation is integrated within the Payogastilla Group, which consist of presents a thickness ca. 1200 m (Diaz \& Malizzia, 1983), and it is bounded by the subjacent Angastaco and the superjacent San Felipe formations (Figure 1). Lithologically Palo Pintado strata consists in cycles of decreasing grains that includes conglomerates at the base and a transition into a sandstone matrix that culminates in a greenish siltstone at top (Herbst et al., 1987; Anzótegui, 1998, Galli et al., 2011). The fossil originate from basal most to middle section of the formation, which crops out at Quebrada del Horno and Peñas Blancas, in Salta Province.

\section{MATERIAL AND METHODS}

The impressions of Blechnum serrulatiformis and Thelypteris interrupta from Quebrada del Horno and Peñas Blancas are found in outcrops of Palo Pintado Formation, from Upper Miocene strata, occurring as intact and fragmented material. Nearly all complete fronds were found with venation and even with sori occurred in a few fronds of T. interrupta. The analyzed material is deposited in the Paleobotany (CTESPB) and Ichnology (CTES-IC) collections of the Facultad de Ciencias Exactas y Naturales y Agrimensura of the Universidad Nacional del Nordeste, in Corrientes, Argentina. The fossil impressions were compared with extant samples of Thelypteris interrupta and Blechnum serrulatum Richard 1792, wich are deposited in the CTES herbarium, in Corrientes Province.

Material was observed in a Nikon binocular stereomicroscope, model SMZ-445 and photographed with Nikon mounted camera (model 590CU). Micrometrics software (image processor) was used for measurements, principally of insect damage dimensions.

\section{SYSTEMATIC ICHNOLOGY}

Family PHAGOPHYTICHNIDAE Vialov, 1975

Subfamily FOLIFENESTRINAE Vasilenko, 2007a

Folifenestra Vasilenko, 2007a

Type ichnospecies. Folifenestra dubia Vasilenko, 2007a (p. 208, pl. 12, figs. 6,7).

Emended diagnosis. Hole feeding damage variable in size and shape, grouped or isolated, occupying part or all the space between two secondary veins. The margin of the perforation range from a fine dark line to a more robust thickened rim.

Remarks. The diagnosis is emended because Vasilenko (2007a) defined the ichnogenus only as "windows feeding", without offering any morphological character for its identification. Moreover, the author restricted the definition of the ichnogenus only for Pteridophyta and Pinophyta, and no potentially applying the designation to other families of plants. According to the illustrated material and their citations (Vasilenko, 2007a, pl. 12, figs. 6,7), the author was probably referring to hole feeding traces. However, Vasilenko (2007a) defined the traces as window feeding traces, which represent another type of feeding behavior, resulting in a misapplied definition.

Folifenestra intervenosa isp. nov. (Figures 2A-F; 3A,B; 4C,F)

Holotype. CTES-IC 35, traces on pinna of Thelypteris interrupta (CTES-PB 14142), (Figure 2A).

Paratype. CTES-IC 34, traces on pinna of Thelypteris interrupta (CTES-PB 14141), (Figures 2C,D; 3A; 4F).

Host. Blechnum serrulatiformis (Blechnaceae) (CTESPB 8061, CTES-PB 14064), Thelypteris interrupta (Thelypteridaceae).

Other material examined. Specimens CTES-IC 32, CTESIC 33, CTES-IC 37 (Figure 2B), CTES-IC 62, CTES-IC 64, CTES-IC 65, CTES-IC 66, CTES-IC 67, CTES-IC 68 and CTES-IC 69 occur on pinnules of Thelypteris interrupta (CTES-PB 14139, 14140, 14143, 14144, 14145, 14146, 14147, 14148, 14149 and 14150; paleobotanical collection number assigned at fossil plants containing those traces).

Provenance and stratigraphy. Peñas Blancas outcrop, Palo Pintado Formation, Salta Province, Argentina.

Etymology. For the leaf part where the traces are placed. Latin, inter (between) and vena (of the veins). 

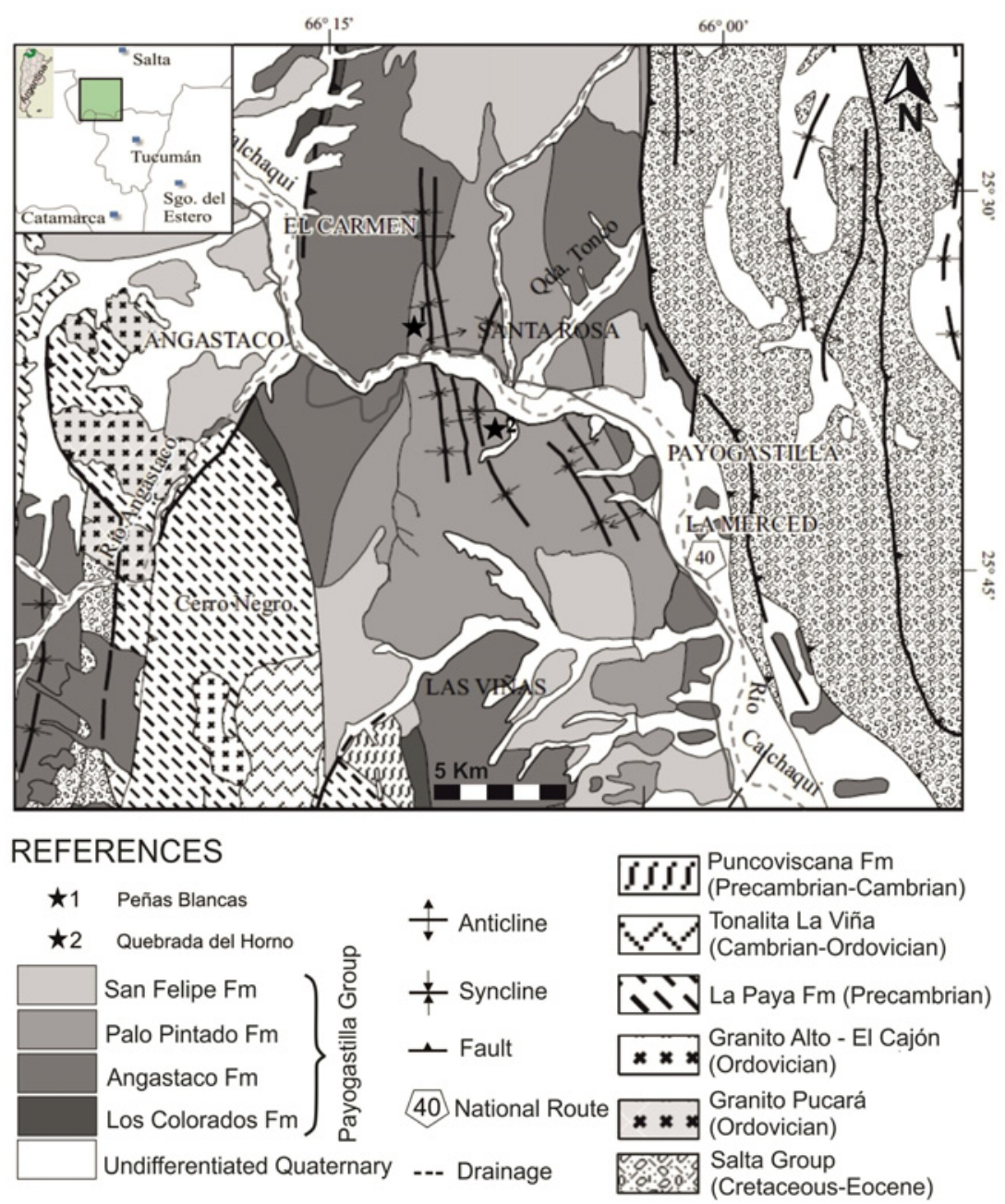

Figure 1. Map of fossiliferous outcrops (edited from Galli et al., 2011).

Diagnosis. Hole feeding traces, oblong in shape and with rounded ends, occupying almost the entire space between two secondary veins. Secondary veins are never removed. The proximal ends of the traces are always in contact with the midvein and distal ends never touch leaf margins. Lateral margins of the traces always touch the secondary veins.

Description. Folifenestra intervenosa isp. nov. is found both in pinnae of Blechnum serrulatiformis (Figures 2E-F; 4C) and Thelypteris interrupta (Figures 2A-D, G; 4F). The traces are deployed to in one or both sides of the midvein (i.e. in both hemilaminas). The excisions are distributed either consecutively and separated by secondary veins or otherwise are isolated, but both types are never evident in the same lamina. Usually traces are located at the proximal portion of the fern lamina. The measured lengths varied from $0.45 \mathrm{~mm}$ to $4.12 \mathrm{~mm}$. The measured widths vary from 0.26 to $0.93 \mathrm{~mm}$ ( $N=135)$. In Blechnum serrulatiformis hole feeding excisions reach the margin of the leaf lamina, whereas in Thelypteris interrupta traces occupied three-fourths of hemilamina and usually they are located at the base of the leaf.

Remarks. Givulescu (1984) described the ichnospecies Phagophytichnus circumsecans and P. nigromarginatus for hole feeding traces. Originally, Givulescu (1984) included in $P$. circumsecans both marginal excisions and hole feeding damage. $P$. circumsecans differs from Folifenestra intervenosa isp. nov. because traces are circular to ovoidal in shape and do not occupy all of the space between the two secondary veins. $P$. nigromarginatus also differs from $F$. intervenosa isp. nov. in that the hole-feeding traces are not adjacent to the primary vein. Examples of hole feeding documented by Labandeira et al. (2002 p. 309; figs. 5a-c, e, f, h, i) mostly are circular to ovoidal in shape. Several samples are in contact with a primary vein, but every trace, generally did not contact both adjacent secondary veins. Labandeira et al. (2007) recorded "hole feeding traces in intercostal area" (p. 7; DT 78), although the tissue between the veins is not completely removed, in particular two consecutive hole-feeding traces are only separated from each other by a secondary vein. Finally, hole feeding damage documented by Gallego et al. (2014) are different from $F$. intervenosa isp. nov. as the hole feeding damages are not in contact with the primary vein (midrib).

\section{Infderefolia igen. nov.}

Type ichnospecies. Infderefolia oblonga, by monotypy. 


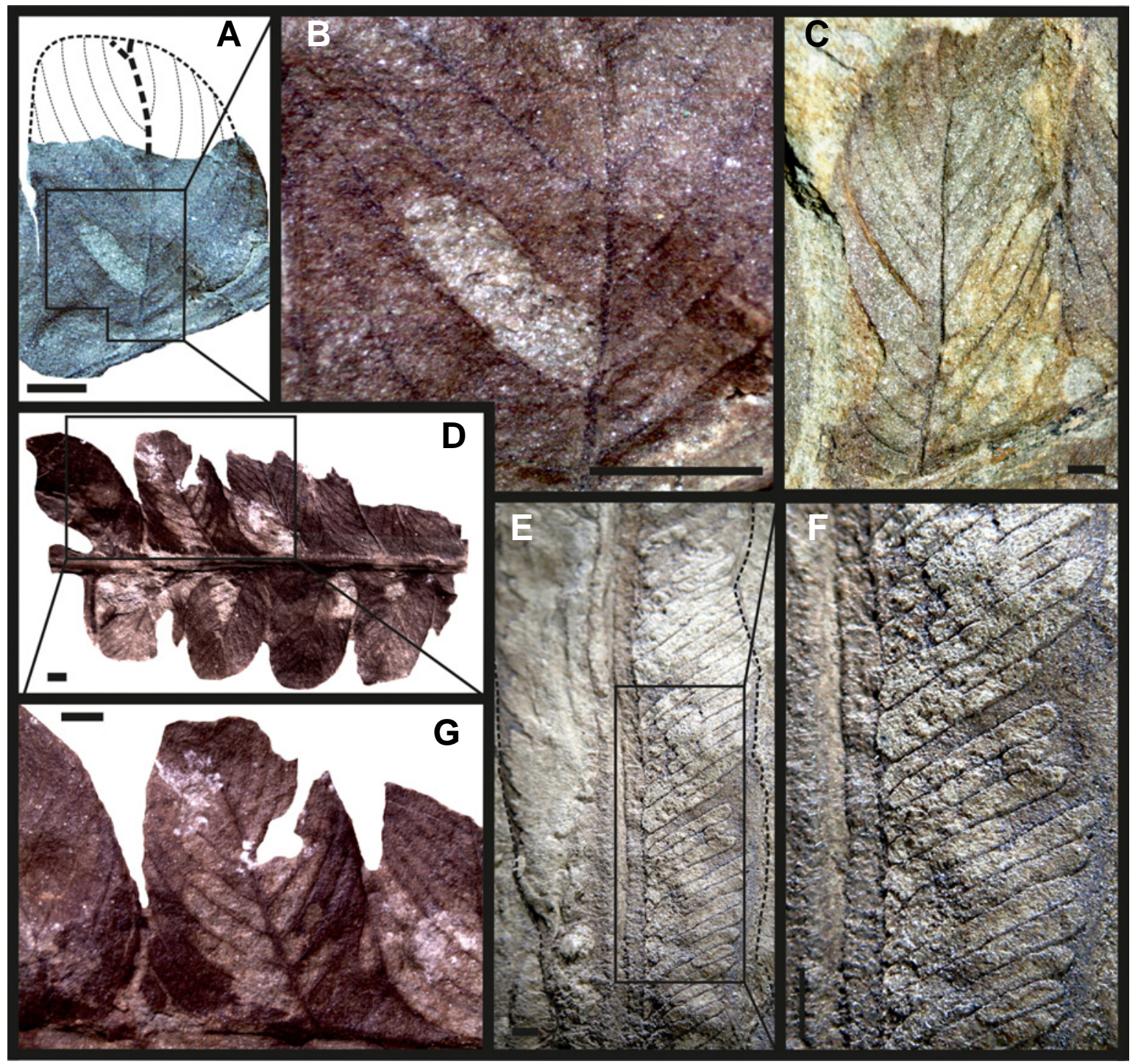

Figure 2. A-G, Folifenestra intervenosa isp. nov.; E-F, Infderefolia oblonga isp. nov.; A-D and G, Thelypteris interrupta (CTES-IC 37,35 holotype and 34); E-F, Blechnum serrulatiformis (CTES-IC 11 paratype); C-G, these samples show grouped excisions (F and $\mathbf{G}$, details of E and D respectively); A-B, sample showing single trace. Scale bars $=1 \mathrm{~mm}$.

Etymology. In reference to the type of trace. Latin, infmdere (deep cut) and folia (leaves).

Diagnosis. Surface feeding damage variable in size and shape, grouped or isolated, occupying part or all the space between two secondary veins. Only one epidermis remains. The color and hue of the excision is similar to that of the leaf lamina but clearer. Excision margins frequently contain a fine dark line.

Remarks. The diagnosis of the subfamily Folifenestrinae (Vasilenko, 2007a) contemplate both surface feeding as hole feeding damage. Thus, the ichnogenus Infderefolia igen. nov. is included in this subfamily together with the ichnogenus Folifenestra. The ichnogenus Infderefolia igen. nov. is assigned to surface feeding, whereas Folifenestra correspond with hole feeding damage.

Infderefolia oblonga igen nov. et isp. nov. (Figures 3B; 4C)
Holotype. CTES-IC 11, traces on pinna of Blechnum serrulatiformis (CTES-PB 8061); (Figure 4C).

Paratype. CTES-IC 17, traces on the pinna of Blechnum serrulatiformis (CTES-PB 14064).

Host. Blechnum serrulatiformis (Blechnaceae).

Other material examined. CTES-IC 12; host plant, Blechnum serrulatiformis (CTES-PB 8062).

Provenance and stratigraphy. Quebrada del Horno outcrop; Palo Pintado Formation, Salta Province, Argentina.

Etymology. In reference to the shape of damage.

Diagnosis. Surface feeding, oblong in shape, with both ends of damage rounded. Traces occupy the entire intercostal space between two secondary veins. The primary and secondary veins are always present.

Description. Infderefolia oblonga igen nov. et isp. nov. was found on pinnae of Blechnum serrulatiformis (Figures 2E-F; 4C) and Thelypteris interrupta. Surface feeding occurs on one 

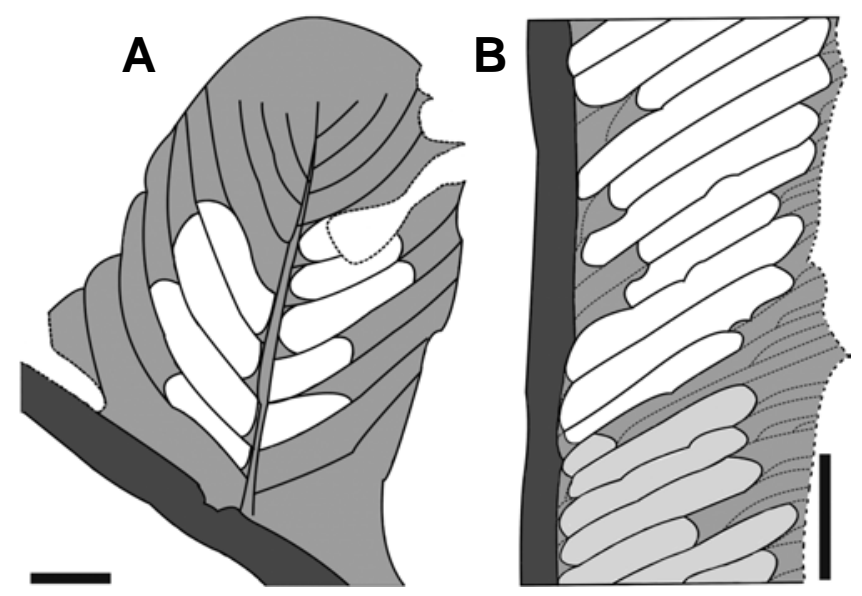

Figure 3. A, Schema showing Folifenestra intervenosa isp. nov. in Thelypteris interrupta (CTES-IC 34) and B, Infderefolia oblonga isp. nov. and Folifenestra intervenosa isp. nov. in Blechnum serrulatiformis (CTES-IC 11 paratype). White: Folifenestra intervenosa isp. nov.; light grey: Infderefolia oblonga isp. nov.; dark grey: rachis in Thelypteris interrupta and midvein in Blechnum serrulatiformis; dotted lines: leaf breakage. Scale bars $=1 \mathrm{~mm}$.

or both sides of the primary vein, distributed in a consecutive series between secondary veins or as isolated surface feeding. Both types of distribution are never represented in the same lamina. The measured lengths varied from $0.76 \mathrm{~mm}$ to 3.43 $\mathrm{mm}$. The measured widths varied from $0.24 \mathrm{~mm}$ to $0.47 \mathrm{~mm}$ $(\mathrm{N}=32)$ reaching the margin of the leaf lamina.

Remarks. Infderefolia oblonga igen. nov. et isp. nov. differs from Phagophytichnus gastropodinus Givulescu (1984) as the latter ichnospecies presents an irregular arrangement on the leaf, semicircular shape and occurring in a consecutive and parallel series. Infderefolia oblonga igen. nov. et isp. nov. differs from window feeding traces documented by Ash (1997, p. 239, fig. 2E; p. 241, 3c,f) as the traces of the damaged leaf are arranged in a group and not isolated. By contrast, other surface feeding documented by Ash reveals an oval shape and breach the secondary veins. Wilf et al. (2000) described the ichnospecies Cephaloleichnites strongi (Wilf, Labandeira, Kress, Staines, Windsor, Allen \& Johnson, 2000), which are elongated with rounded lateral borders and located between parallel veins of third-order rank. The surface feeding of Cephaloleichnites strongi is not adjacent to the midvein and thus, differs from Infderefolia oblonga igen. nov. et isp. nov.

\section{DISCUSSION}

One type of insect phytophagy on ferns (Table 1) consists principally of galleries that containing coprolites in the rachises, stems and petioles of tree ferns. These occurrences are recorded from the Lower Carboniferous to Cretaceous, mostly from the Northern Hemisphere (Seward, 1923, 1924; Rothwell \& Scott, 1983; Scott \& Taylor, 1983; Scott \& Paterson, 1984; Rex \& Galtier, 1986; Labandeira \& Beall, 1990; Lesnikowska, 1990; Tidwell \& Hebbert, 1992; Labandeira et al., 1997; Ash, 2000; Labandeira \&
Phillips, 2002; Rößler, 2000; D’Rozario et al., 2011). These occurrences were reported mostly in the stems of Psaronius Cotta, 1832 a marattialean tree fern (Rothwell \& Scott, 1983; Labandeira \& Beall, 1990; Lesnikowska, 1990; Labandeira \& Phillips 1996a,b; Labandeira et al., 1997; Labandeira \& Phillips, 2002; Rößler, 2000; D’Rozario et al., 2011) and Tempskya Corda, 1845 a probable filicalean tree fern (Seward, 1923, 1924; Scott \& Paterson, 1984; Tidwell \& Hebbert, 1992). Less common occurrences of insect damage are galls (Labandeira \& Phillips, 1996b; Labandeira \& Phillips, 2002), piercing and sucking (Scott \& Taylor, 1983; Labandeira \& Phillips, 1996a) and marginal excisions (Ash, 1997; Labandeira, 2002b) which have been recorded from the Carboniferous to the Eocene of the USA. In the Southern Hemisphere, there are few records of coprolites occurring in tissues of ferns from Permian and Triassic deposits of Antarctica (Kellogg \& Taylor, 2004; Slater et al., 2012). Only three reports of folivory are known on Jurassic fossil ferns from Australia (Hill, 1987; McLoughlin et al., 2015) and early Eocene from Argentina (Carvalho et al., 2013) and one record of piercing-and-sucking on filicalean fern from Jurassic of Australia (McLoughlin et al., 2015). The first evidences of folivory in ferns appeared in the Late Triassic from USA and China. These traces correspond with marginal excisions on Cynepteris lasiophora Ash, 1969 (Ash, 1997), and skeletonizations on Dictyophyllum nathorstii Zeiller, 1903 (Feng et al., 2014). In Middle Jurassic from Australia have been documented hole feeding traces on Angiopteris blackii van Cittert, 1975 (Hill, 1987) and marginal and hole feeding damages on Cladophlebis australis Morris, 1845 (McLoughlin et al., 2015).

Surface feeding and hole feeding damages on other groups of vascular plants, particularly seed plants are more abundant compared with those recorded on ferns (Table 2). The oldest surface feeding was described in leaves of Comia sp. from the Lower Permian of USA (Beck \& Labandeira, 1998). De Souza Pinheiro et al. (2012) described surface feeding on Glossopteris indica Schimper, 1869 and G. communis Feistmantel, 1876 leaves from Lower Permian of Brazil and Gallego et al. (2014) also documented those damage types on Glossopteris, Ginkgoites and Cordaites Unger, 1850 leaves from approximately the same age in Argentina. Ash (1997) described elongate surface feeding in pinnae of Zamites sp. (Bennettitales) from the Upper Triassic of USA. Other occurrence bennettitaleans was reported by Banerji (2004), who documented a circular window excision on Ptilophyllum sp. from the Lower Cretaceous of India. Labandeira et al. (2002) found surface feeding with elongated shape located between secondary veins on a leaf of Nilssonia yukonensis Hollick, 1930 (Nilssoniales) from the latest Cretaceous of the USA. Surface feeding occurring on angiosperms were the described on two species of Zingiberales from the Upper Cretaceous and Lower Eocene of the USA (Wilf et al., 2000) and those reported by Givulescu (1984) on Acer integerrimum Viviani, 1833 from Upper Miocene of Romania. Hole feeding damage is more abundant in the fossil record and older comparing with surface feeding. The fossil record of hole feeding is 


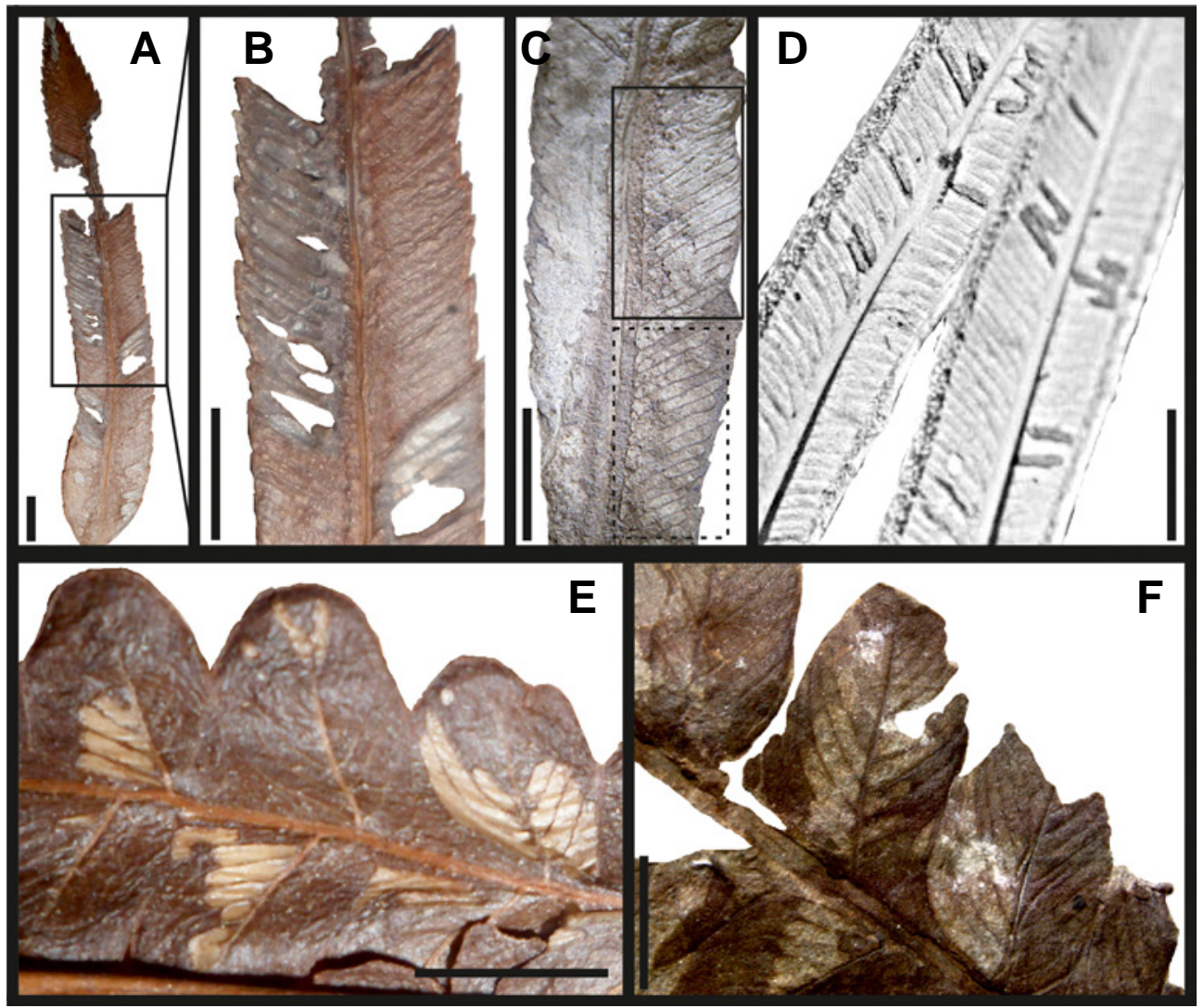

Figure 4. Comparison of traces identified in fossil plants with extant samples. A, Blechnum serrulatum, the image shows surface feeding and hole feeding between the secondary veins; B, Detail of traces in A; C, Blechnum serrulatiformis (CTES-IC 11 paratype), surface feeding and hole feeding identical at those observed in $\mathbf{A}$ and $\mathbf{B}$. Dotted line corresponds with surface feeding (Infderefolia oblonga isp. nov.) and continuous line with hole feeding (Folifenestra intervenosa isp. nov.). D, image edited from Patra \& Bera (2007), it can to observe surface feeding on pinna of Pteris vittata; E and F, Thelypteris interrupta; E, an extant sample that presents surface feeding; F, fossil sample (CTES-IC 34) showing the same traces that in $\mathbf{E}$. Scale bars $=5 \mathrm{~mm}$.

almost continuous since Upper Carboniferous (Castro, 1997; Trout et al., 2000) and extends to Pliocene (Straus, 1977). Until the Mid-Lower Cretaceous these traces were described on gymnosperms (Medullosales, Gingantopteridales, Cordaitales, Cycadales, Peltaspermales, Glossopteridales, Ginkgoales) and Sphenopsids, predominately from the Northern Hemisphere (North America and Europe), by Ash (1972, 1997), Castro (1997), Grauvogel-Stamm \& Kelber (1996), Beck \& Labandeira (1998), Labandeira (2006), Trout et al. (2000), Glasspool et al. (2003), Labandeira \& Allen (2007), Vasilenko (2007a). Moreover, there are a few preCretaceous records in South America that include circular to slot holes on Cordaites, Gangamopteris McCoy, 1875 and Glossopteris leaves from the Lower Permian of Brazil (Adami-Rodrigues et al., 2004; De Souza Pinheiro et al., 2012); circular to elliptical hole feeding traces in Glossopteris wilsonii Seward, 1914 and Ginkgoites eximia Feruglio, 1942 from the Early Permian of Argentina (Gallego et al., 2014); hole and marginal feeding, leaf-mines and skeletonizations in different plant species from Middle-Late Triassic of Argentina (Adami-Rodrigues et al., 2012) and hole feeding on leaves of Taeniopteris sp. from Upper Triassic of Chile (Gallego et al., 2003). From the mid-Cretaceous to Neogene, hole-feeding damages were described exclusively on angiosperms from the
Northern Hemisphere (Straus, 1977; Givulescu, 1984; Scott et al., 1992; Stephenson \& Scott, 1992; Labandeira, 1998; Wilf et al., 2000; Labandeira, 2002a,b; Labandeira et al., 2002; Krassilov, 2008; Krassilov \& Shuklina, 2008; Wappler, 2010; Wappler \& Denk, 2011). For the Southern Hemisphere, the only for circular hole feeding is on Nectandra saltensis Anzótegui, 1988 and Sapium haematospermoide Anzótegui \& Horn, 2011 from the Late Miocene of Argentina (Horn et al., 2011). The extensive record of hole feeding in angiosperms during the mid-Cretaceous, is coincident with the extinction of most gymnosperms (Niklas et al., 1983; Taylor et al., 2009), which could demonstrate a variation and shift in the preferences of insects to alternative host plants.

Currently, the predominant type of fern-insect interaction is herbivory (Cooper-Driver, 1985a; Mehltreter, 2010), although mutualism are also know (Auerbach \& Hendrix, 1980; Cooper-Driver, 1985b; Tryon, 1985). Some studies revealed that phytophagous insects prefer to feed on angiosperms more than on ferns (Brues, 1920; Soo Hoo \& Fraenkel, 1964; Hendrix, 1980), which would explain the scanty record of these associations in both in extant and fossil ferns. Two opposite explanations about the preference of insects to angiosperm compared with ferns were proposed. One explanation is that ferns are poorly attacked by insects, 
Table 2. Fossil record of surface feeding (SF) and hole feeding (HF), on sphenopsids and seed plants.

\begin{tabular}{|c|c|c|c|}
\hline Interaction type & Taxa & Age & Author \\
\hline HF & Laburnum sp. (Fabales) & \multirow{2}{*}{ Pliocene } & \multirow{2}{*}{ Straus (1977) } \\
\hline $\mathrm{HF}$ & Parrotia persica (Saxifragales) & & \\
\hline $\mathrm{HF}$ & Sapium sp. (Malpighiales) & \multirow{2}{*}{ late Miocene } & \multirow{2}{*}{ Horn et al. (2011) } \\
\hline $\mathrm{HF}$ & Nectandra saltensis (Laurales) & & \\
\hline $\mathrm{HF}$ & Acer integerrimum (Sapindales) & \multirow{2}{*}{ late Miocene } & \multirow{2}{*}{ Givulescu (1984) } \\
\hline $\mathrm{HF}$ & Alnus sp. (Fagales) & & \\
\hline $\mathrm{HF}$ & Tremophyllum tenerrimum (Urticales) & \multirow{2}{*}{ late Oligocene } & \multirow{2}{*}{ Wappler (2010) } \\
\hline $\mathrm{HF}$ & Alnus menzelii (Fagales) & & \\
\hline $\mathrm{HF}$ & Betula leopoldae (Fagales) & \multirow{6}{*}{ middle Eocene } & \multirow{6}{*}{ Labandeira (2002b) } \\
\hline $\mathrm{HF}$ & Angiosperm sp. indet. & & \\
\hline $\mathrm{HF}$ & Alnus parvifolia (Fagales) & & \\
\hline $\mathrm{HF}$ & Rhus malloryi (Sapindales) & & \\
\hline $\mathrm{HF}$ & Ulmus sp. (Urticales) & & \\
\hline $\mathrm{HF}$ & Sassafras hesperia (Laurales) & & \\
\hline $\mathrm{HF}$ & Angiosperm sp. indet. & middle Eocene & Labandeira (2002a) \\
\hline SF & Zingiberopsis isonervosa (Zingiberales) & early Eocene & Wilf et al. (2000) \\
\hline $\mathrm{HF}$ & Angiosperm sp. indet. & Eocene & Stephenson \& Scott (1992) \\
\hline $\mathrm{HF}$ & 'Corylites' hebridicus & Paleogene & Wappler \& Denk (2011) \\
\hline $\mathrm{HF}$ & Ptemspermites cordata (Dilleniidae) & Paleocene & Labandeira et al. (2002) \\
\hline $\mathrm{HF}$ & Angiosperm sp. indet. & \multirow{11}{*}{ Late Cretaceous } & \multirow{11}{*}{ Labandeira et al. (2002) } \\
\hline $\mathrm{HF}$ & Ulmaceae sp. Indet. & & \\
\hline $\mathrm{HF}$ & Liriodendrites bradacii (Magnoliales) & & \\
\hline $\mathrm{HF}$ & “Dryophyllum” subfulcatum (Magnoliales) & & \\
\hline $\mathrm{HF}$ & “Dryophyllum” tennesseensis (Magnoliales) & & \\
\hline $\mathrm{HF}$ & Grewiopsis saponaria (Platanaceae) & & \\
\hline $\mathrm{HF}$ & Erlingdorfia montana (Platanaceae) & & \\
\hline $\mathrm{HF}$ & “Rhamnus” cleburni (Rhamnaceae) & & \\
\hline $\mathrm{HF}$ & Bisonia niemi (Laurales) & & \\
\hline $\mathrm{HF}$ & Marmarthia trivialis (Laurales) & & \\
\hline SF & Nilssonia yukonensis (Nilsssoniales) & & \\
\hline SF & Zingiberopsis attenuata (Zingiberales) & Late Cretaceous & Wilf et al. (2000) \\
\hline $\mathrm{HF}$ & Angiosperm sp. Indet. & Late Cretaceous & Scott et al. (1992) \\
\hline $\mathrm{HF}$ & Eocercidiphyllites glandulosus (Cercidiphyllales) & middle Cretaceous & Krassilov \& Shuklina (2008) \\
\hline $\mathrm{HF}$ & Dewalquea gerofitica (proangiosperm) & middle Cretaceous & Krassilov (2008) \\
\hline $\mathrm{HF}$ & Crassidenticulum sp. (Laurales) & \multirow{2}{*}{ middle Cretaceous } & \multirow{2}{*}{ Labandeira (1998) } \\
\hline $\mathrm{HF}$ & Pandemophyllum (Laurales) & & \\
\hline SF & Ptilophyllum sp. (Bennettitales) & Early Cretaceous & Banerji (2004) \\
\hline SF? & Otozamites feistmanteli (Gnetopsid) & Jurassic & McLoughlin et al. (2015) \\
\hline $\mathrm{HF}$ & Gontriglossa verticilliata (“Gnetopsid”) & \multirow{2}{*}{ Late Triassic } & \multirow{2}{*}{ Labandeira (2006) } \\
\hline $\mathrm{HF}$ & Yabiella mareyesiaca (“Gnetopsid”) & & \\
\hline $\mathrm{HF}$ & Zamites sp. (Bennettitales) & \multirow{2}{*}{ Late Triassic } & \multirow{2}{*}{ Ash (1997) } \\
\hline SF & Zamites sp. (Bennettitales) & & \\
\hline $\mathrm{HF}$ & Schizoneura paradoxa (Sphenopsid) & Late Triassic & Grauvogel-Stamm \& Kelber (1996) \\
\hline HF & Marcouia neuropteroides (uncertain affinity) & Late Triassic & Ash (1972) \\
\hline $\mathrm{HF}$ & Glossopteris cf. G. ampla (Glossopteridales) & late Permian & Cariglino \& Gutiérrez (2011) \\
\hline $\mathrm{HF}$ & Pursongia sp. (Peltaspermales) & late Permian & Vasilenko (2007a) \\
\hline $\mathrm{HF}$ & Gigantonoclea hallei (Gigantopteridales) & \multirow{2}{*}{ late Permian } & \multirow{2}{*}{ Glasspool et al. (2003) } \\
\hline $\mathrm{HF}$ & Gigantonoclea lagrelii (Gigantopteridales) & & \\
\hline SF & Ginkgoites feruglioi (Ginkgoales) & & \\
\hline SF & Ginkgoites eximia (Ginkgoales) & & \\
\hline SF & Glossopteris wilsonii (Glossopteridales) & early Permian & Gallego et al (2014) \\
\hline SF & Cordaites sp. (Cordaitales) & еarty perminal & Gallego el at. (2014) \\
\hline HF & Glossopteris wilsonii (Glossopteridales) & & \\
\hline $\mathrm{HF}$ & Ginkgoites eximia (Ginkgoales) & & \\
\hline
\end{tabular}


Table 2. Continuation.

\begin{tabular}{|c|c|c|c|}
\hline Interaction type & Taxa & Age & Author \\
\hline SF & Glossopteris indica (Glossopteridales) & \multirow{9}{*}{ early Permian } & \multirow{9}{*}{ De Souza Pinheiro et al. (2012) } \\
\hline SF & Glossopteris communis (Glossopteridales) & & \\
\hline $\mathrm{HF}$ & Cordaites hislopii (Cordaitales) & & \\
\hline $\mathrm{HF}$ & Gangamopteris obovata (Glossopteridales) & & \\
\hline $\mathrm{HF}$ & Gangamopteris buriadica (Glossopteridales) & & \\
\hline $\mathrm{HF}$ & Glossopteris occidentalis (Glossopteridales) & & \\
\hline $\mathrm{HF}$ & Glossopteris indica (Glossopteridales) & & \\
\hline $\mathrm{HF}$ & Glossopteris communis (Glossopteridales) & & \\
\hline $\mathrm{HF}$ & Glossopteris sp. (Glossopteridales) & & \\
\hline $\mathrm{HF}$ & Autunia cf. A. conferta (Peltaspermales) & \multirow{2}{*}{ early Permian } & \multirow{2}{*}{ Labandeira \& Allen (2007) } \\
\hline $\mathrm{HF}$ & Russellites taeniata (Cycadophyta) & & \\
\hline $\mathrm{HF}$ & Cordaites hislopii (Cordaitales) & early Permian & Adami-Rodrigues et al. (2004) \\
\hline SF & Comia sp. (Peltaspermales?) & \multirow{4}{*}{ early Permian } & \multirow{4}{*}{ Beck \& Labandeira (1998) } \\
\hline $\mathrm{HF}$ & Gigantopteridium americanum (Gigantopteridales) & & \\
\hline $\mathrm{HF}$ & Cathaysiopteris yochelsonii (Gigantopteridales) & & \\
\hline $\mathrm{HF}$ & Taeniopteris sp. (Ginkgoales?) & & \\
\hline HF? & Ginkgoites eximia (Ginkgoales) & early Permian & Cúneo (1987) \\
\hline $\mathrm{HF}$ & Macroneuropteris sp. (Medullosales) & Late Carboniferous & Trout et al. (2000) \\
\hline $\mathrm{HF}$ & Mixoneura wagneri (Medullosales) & Late Carboniferous & Castro (1997) \\
\hline
\end{tabular}

probably because of their low nutritional value (Coe et al., 1987), the presence of anti-herbivore chemical compounds (Swain \& Cooper-Driver, 1973; Hendrix, 1977, 1980; Cooper-Driver, 1978, 1990; Rowell et al., 1983), and the absence of nutritionally attractive like fruits, seeds and flowers (Mehltreter, 2010). A complementary explanation proposes that many extant groups of insects have had a close evolutionary history with angiosperms that would be reflected in the higher phytophagy levels on angiosperms (Zwölfer, 1978; Strong et al., 1984). Some authors suggest that ferns reached the peak diversity in the Carboniferous and subsequently declined, which would explain the low number of interactions recorded, both in post-Carboniferous fossil ferns as extant species, if these are compared with angiosperms (Niklas et al., 1983; Tahvanainen \& Niemelä, 1987). In contrast, other authors have proposed a hypothesis that ferns exhibit the similar levels of insect phytophagy to angiosperms (Balick et al., 1978; Auerbach \& Hendrix, 1980; Hendrix \& Marquis, 1983). For instance, ferns present proportions of leaf damage (5\% to 15\%) (Balick et al., 1978; Hendrix \& Marquis, 1983; Mehltreter \& Tolome, 2003; Mehltreter et al., 2006) that are similar to those reported for angiosperms in tropical forests (Lowman, 1984, 1985; Coley \& Aide, 1991; Williams-Linera \& Baltazar, 2001). In addition, Hummel et al. (2008) demonstrated that leaf tissues of ferns and seed plants provide similar amounts and types of nutrients.

Despite their abundant fossil record, the ichnotaxonomy of hole feeding, was poorly treated in the literature. The few records that have documented hole feeding damages were included in the ichnogenus Phagophytichnus van Amerom, 1966 (Straus, 1977; Givulescu, 1984), for which several morphologies of hole feeding were described from the early Pliocene of Germany Straus (1977). Following Straus
(1977), Givulescu (1984) documented examples of hole feeding in the same ichnospecies and established additional icnotaxa from the late Miocene of Romania. Nevertheless, the ichnogenus Phagophytichnus was created originally by van Amerom (1966) for marginal excisions. Sarzetti et al. (2008) proposed to restrict Phagophytichnus only for margin-feeding traces as defined originally by van Amerom (1966). This restriction is because marginal and hole feeding damage involves two distinct morphological patterns which are the result of two different feeding behaviors, related to particular insect mouthparts design and strategies for energy conservation (Edwards \& Wratten, 1980). With hole feeding, few studies that have documented surface feeding provided formal ichnotaxonomic assignments. The first ichnospecies of surface feeding was described by Givulescu (1984), who defined Phagophytichnus gastropodinus in Acer integerrimum (Sapindales). Although the author did not mention this ichnospecies as surface feeding, the characters showed by the author in the figures (p. 130, pl. VI, fig. 1) demonstrated that P. gastropodinus represented a surface feeding. Later, Wilf et al. (2000) described the ichnospecies Cephaloleichnites strongi, assigned to beetles, which consisted in surface feeding that formed as linear strips along parallel veins. More recently, Vasilenko (2007a) defined the ichnogenus Folifenestra, assigned to the single ichnospecies dubia, to include traces he called "window feeding". However, the illustrated material suggests that the author was referring most likely to hole feeding instead surface feeding excisions. It is proposed here to emend the diagnosis of Folifenestra to include only hole feeding excisions and define the new ichnogenus Infderefolia igen. nov. for surface feeding.

Based on shape, pattern and arrangement on the leaf, Folifenestra intervenosa and Infderefolia oblonga igen. nov. 
et isp. nov., may be produced by leaf beetles (Coleoptera: Chrysomelidae). Several studies documenting the feeding behavior of leaf beetles on extant plants showed similar patterns to the new ichnospecies described here. For example, Patra \& Bera (2007) demonstrated that adults of at least one species of Chrysomelidae, Schenklingia bhaumiki Basu \& Sen Gupta, 1982 (Tribe Alticini) feeds on ten fern species of the families Adiantaceae, Thelypteridaceae, Polypodiaceae, Nephrolepidaceae and Pteridaceae. The adults Schenklingia bhaumiki produce window excisions in Pteris vittata Linné, 1753 (Figure 4D) consuming selectively the tissues between veins. The beetles move on the adaxial or abaxial surface of the fronds, initially exploring the central region of the pinnule, removing all tissues except the epidermis that later can be consumed, creating holes in the lamina. This evidence could indicate that both $F$. intervenosa isp. nov. and I. oblonga igen. nov. et isp. nov. are the result of the same species, a phenomenon recently recognized in a study of herbivory of lowland modern tropical forest (Carvalho et al., 2014). Window excisions similar to I. oblonga igen. nov. et isp. nov. also were recorded on extant angiosperms. Strong (1977) described four different types of feeding behaviors of beetles in Zingiberales monocotyledon angiosperms. One type consisted in scraping across the plant surface, which was called "strip mining" (Strong, 1977). These traces were attributed to four species of chrysomelids, Chelobasis perplexa Baly, 1858, Xenarescus monocerus Olivier, 1808, Nympharescus separatus Baly, 1858 (all Tribe Arescini) and Cephaloleia consanguinea Baly, 1885 (Tribe Cephaloliini). Magalhães et al. (2012) identified traces which are comparable with I. oblonga igen. nov. et isp. nov. on leaves of Aechmea blanchetiana Baker, 1955 (Bromeliaceae) produced by Acentroptera pulchella Guérin-Méneville, 1830 (Chrysomelidae, Hispinae). Beetles scrape the lamina of $A$. pulchella leaving only few layers of cells of mesophyll and epidermis. Wilf et al. (2000) described the ichnospecies Cephaloleichnites strongi that represent surface feeding in fossil leaves of Zingiberales. These authors attributed this ichnospecies to members of the Tribe Cephaloliini (Coleoptera: Chrysomelidae). However, García-Robledo et al. (2007) and García-Robledo \& Staines (2008) described surface feeding with a similar morphology as $C$. strongi in extant Zingiberales species caused by the Curculionidae (Coleoptera) and larval stages of Pyralidae and Choreutidae (Lepidoptera). These authors proposed these insects as potential producers of $C$. strongi. Chrysomelidae also are recorded as body fossils since the Late Jurassic (Ponomarenko, 2002), mainly from the Northern Hemisphere (Santiago-Blay, 1994), although a few records occur in South America. In Argentina, there is a description of a chrysomelid from the Paleogene (Cockerell, 1926). Currently, this family is recorded in the central and northern part of Argentina (Blackwelder, 1957; Cabrera et al., 1997; Defagó et al., 2010; Cabrera \& Rocca, 2012).

Extant samples of Blechnum serrulatum (Blechnaceae) and Thelypteris interrupta (Thelypteridaceae) housed in the CTES Herbarium were investigated for insect damage and were analyzed to compare their morphology with $F$. intervenosa isp. nov. and I. oblonga igen. nov. et isp. nov.. The insect damage either on $B$. serrulatum and $T$. interrupta are similar to I. oblonga igen. nov. et isp. nov.. Traces are oblong excisions with both ends very rounded and arranged faithfully between two secondary veins (Figures 4A). They are grouped, without remove the upper epidermis and resulting in window excisions. As in I. oblonga igen. nov. et isp. nov., extant excisions occupy the entire intercostal area. In $T$. interrupta hole-feeding traces were also recorded, but these traces are not as comparable to $F$. intervenosa isp. nov. because both the secondary veins and the primary vein of the pinnae are consumed. Unfortunately, the producer of the traces in extant ferns was not identified because there are no current records of insects associated with extant species of T. interrupta and B. serrulatum (Farias, pers. comm. 2013). More work on extant fern species is needed in order to assess the potential producer of I. oblonga igen. nov. et isp. nov. and F. intervenosa isp. nov..

\section{CONCLUSIONS}

This study reports the second fossil record of fern-insect interactions from Argentina and the first record of window excisions on fossil ferns. Despite that the producer of the new ichnospecies Infderefolia oblonga igen. nov. et isp. nov. and Folifenestra intervenosa isp. nov. remains unclear, both ichnogenera reveal a Neogene fern-insect interaction and is a contribution to sparse record of fern-insect relationships. Moreover, the Palo Pintado Formation offers a potential opportunity to study novel insect interactions of the past. Further exploration is needed to achieve greater understanding of the trophic interaction of this biota from the Miocene of Argentina.

\section{ACKNOWLEDGEMENTS}

We thank M. Ponce, K. Mehltreter, R. Moran, C. Godoy and $\mathrm{X}$. Farias for helping in the interpretation of the fossil traces; J. Genise for critical reading of the manuscript. The Corrientes Herbarium provided extant samples to analyze. Funding for this project was provided by the Proyecto de Investigación Científica y Tecnológica PICT-2007-00124 and PI 17/F161 SECYT-UNNE to L. M. Anzótegui; PI F021 SECYT-UNNE to S. Garralla.

\section{REFERENCES}

Adami-Rodrigues, K.; Gnaedinger, S. \& Gallego, O.F. 2012. Análise de interação inseto-planta do Grupo El Tranquilo (Triássico Médio-Superior), Santa Cruz, Argentina. Ameghiniana, 49:R108.

Adami-Rodrigues, K.; Iannuzzi, R. \& Pinto, I.A. 2004. Permian plant-insect interactions from a Gondwana flora of southern Brazil. Fossils and Strata, 51:106-125.

Anzótegui, L.M. 1992. Una flora del Mioceno superior (Formación Palo Pintado) del noroeste Argentino. Asociación Paleontológica Argentina, 2:7-10.

Anzótegui, L.M. 1998. Hojas de angiospermas de la Formación Palo Pintado, Mioceno Superior, Salta, Argentina. Parte I: Anacardiaceae, Lauraceae y Moraceae. Ameghiniana, 35:25-32. 
Anzótegui, L.M. \& Horn, M.Y. 2011. Megaflora de la Formación Palo Pintado (Mioceno Superior) Salta, Argentina. Parte II. Revista Brasileira de Paleontologia, 14:239-254. doi:10.4072/ rbp.2011.3.4

Anzótegui, L.M.; Horn, M.Y. \& Adami-Rodrigues, K. 2008. Interacciones biológicas insecto-planta fósiles en las Formaciones San José (Mioceno Medio) y Palo Pintado (Mioceno Superior), noroeste de Argentina. In: SIMPOSIO DE PALEOBOTÁNICOS Y PALINÓLOGOS, 12, 2008. Abstracts, Florianópolis, p. 5.

Ash, S.R. 1972. Late Triassic plants from the Chinle Formation in northeastern Arizona. Palaeontology, 15:598-618.

Ash, S.R. 1997. Evidence of arthropod-plant interactions in the Upper Triassic of the southwestern United States. Lethaia, 29:237-248. doi:10.1111/j.1502-3931.1996.tb01657.x

Ash, S.R. 2000. Evidence of oribatid mite herbivory in the stem of a Late Triassic tree fern from Arizona. Journal of Paleontology, 74:1065-1071. doi:10.1666/0022-3360(2000)074<1065:EOO MHI $>2.0 . C O ; 2$

Auerbach, M.J. \& Hendrix, S.D. 1980. Insect-fern interactions: macrolepidopteran utilization and species-area association. Ecological Entomology, 5:99-104. doi:10.1111/j.1365-2311.1980. tb01129.x

Balick, M.J.; Furth, D.G. \& Cooper-Driver, G.A. 1978. Biochemical and evolutionary aspects of arthropod predation on ferns. Oecologia, 35:55-89. doi:10.1007/BF00345541

Bancroft, H. 1932. A fossil cyatheoid stem from Mount Elgon, East Africa. New Phytologist, 31:241-253. doi:10.1111/j.1469-8137.1932.tb06780.x

Banerji, J. 2004. Evidence of insect-plant interactions from the Upper Gondwana Sequence (Lower Cretaceous) in the Rajmahal Basin, India. Gondwana Research, 7:205-210. doi:10.1016/ S1342-937X(05)70320-8

Beck, A.L. \& Labandeira, C.C. 1998. Early Permian insect folivory on gigantopterid- dominated riparian flora from north-central Texas. Palaeogeography, Palaeoclimatology, Palaeoecology, 142:139-173. doi:10.1016/S0031-0182(98)00060-1

Blackwelder, R.E. 1957. Checklist of the coleopterous insects of Mexico, Central America, the West Indies, and South America. Parts 1-6. Washington, the United States National Museum, 1492 p. (Bulletin 185).

Brues, C.T. 1920. The selection of food-plants by insects, with special reference to lepidopterous larvae. The American Naturalist, 54:313-332. doi:10.1086/279763

Cabrera, N.; Alvarez, H.A.; López, A.N. \& Vincini, A. 1997. Una nueva plaga potencial de papa en Argentina, Maecolaspis bridarollii (Bechyné) (Coleoptera, Chrysomelidae, Eumolpinae). Revista Latinoamericana de la Papa, 9:188-199.

Cabrera, N. \& Rocca, M. 2012. First records of Chrysomelidae (Insecta, Coleoptera) on blueberries in Argentina: new associations between native chrysomelids and an exotic crop. Revista de la Sociedad Entomológica Argentina, 71:45-55.

Cariglino, B. \& Gutiérrez, P.R. 2011. Plant-insect interactions in a Glossopteris flora from the la Golondrina Formation (Guadalupian-Lopingian), Santa Cruz Province, Patagonia, Argentina. Ameghiniana, 48:103-112.

Carvalho, M.R.; Wilf, P.; Barrios, H.; Windsor, D.M.; Currano, E.D.; Labandeira, C.C. \& Jaramillo, C.A. 2014. Insect leaf-chewing damage tracks herbivore richness in modern and ancient forests. PLoS ONE, 9:e94950. doi:10.1371/journal.pone.0094950

Carvalho, M.R.; Wilf, P.; Hermsen, E.J.; Gandolfo, M.A.; Cúneo, N.R. \& Johnson, K.J. 2013. First record of Todea (Osmundaceae) in South America, from the Early Eocene paleorainforests of
Laguna del Hunco (Patagonia, Argentina). American Journal of Botany, 100:1831-1848. doi:10.3732/ajb.1200637

Castro, M.P. 1997. Huellas de la actividad biológica sobre plantas del Estefaniense superior de la Magdalena (León, España). Revista Española de Paleontología, 12:52-66.

Césari, S.N.; Busquets, P.; Méndez-Bedia, I.; Colombo, F.; Limarino, C.O.; Cardó, R. \& Gallastegui, G. 2012. A late Paleozoic fossil forest from the southern Andes, Argentina. Palaeogeography, Palaeoclimatology, Palaeoecology, 333-334:131-147. doi:10.1016/j.palaeo.2012.03.015

Cockerell, T.D.A. 1926. Some Tertiary fossil insects. The Annals and Magazine of Natural History, 18:313-324. doi:10.1080/00222932608633519

Coe, M.L.; Dilcher, D.L.; Farlow, J.O.; Jarzen, D.M. \& Russell, D.A. 1987. Dinosaurs and land plants. In: E.M. Friis; W.G. Chaloner \& P.R. Crane (eds.) The Origins of Angiosperms and their Biological Consequences, Cambridge University Press, p. 225-258.

Coley, P.D. \& Aide, T.M. 1991. Comparison of herbivory and plant defenses in temperate and tropical broad-leaved forests. In: P.W Price; T.M. Lewinsohn; G.W. Fernandes \& W.W Benson (eds.) Plant-animal interactions: evolutionary ecology in tropical and temperate regions, John Wiley \& Sons, p. 25-49.

Cooper-Driver, G.A. 1978. Insect-fern associations. Entomologia Experimentalis et Applicata, 24:310-316. doi:10.1111/j.1570-7458.1978.tb02787.x

Cooper-Driver, G.A. 1985a. Anti-predation strategies in Pteridophytes: a biochemical approach. Proceedings of the Royal Society of Edinburgh, 86:397-402. doi:10.1017/ S0269727000008381

Cooper-Driver, G.A. 1985b. The distribution of insects on ferns. American Journal of Botany, 72:921.

Cooper-Driver, G.A. 1990. Defense strategies in bracken, Pteridium aquilinum (L.) Kuhn. Annals of the Missouri Botanical Garden, 77:281-286. doi:10.2307/2399541

Coutand, I.; Caparra, B.; Diiken, A.; Schmitt, A.K.; Sobel, E.R. \& Strecker, M.R. 2006. Propagation of orographic barriers along and active range front: insights from sandstone petrography and detritial apatite fission-track thermochronology in the intramontane Angastaco basin, NW Argentina. Basin Research, 18:1-26. doi:10.1111/j.1365-2117.2006.00283.x

Cúneo, R.N. 1987. Sobre presencia de probable Ginkgoales Pérmico Inferior de Chubut, Argentina. In: SIMPOSIO ARGENTINO DE PALEOBOTÁNICA Y PALINOLOGÍA, 7, 1987. Actas, Buenos Aires, p. 47-50.

D’Rozario, A.; Labandeira, C.C.; Guo, W.Y.; Yao, Y.F. \& Li, C.S. 2011. Spatiotemporal extension of the Euramerican Psaronius component community to the late Permian of Cathaysia: in situ coprolites in a $P$. housuoensis stem from Yunnan Province, southwest China. Palaeogeography, Palaeoclimatology, Palaeoecology, 306:127-133. doi:10.1016/j.palaeo.2011.04.009

De Souza Pinheiro, E.R.; Iannuzzi, R. \& Tybusch, G.P. 2012. Specificity of leaf damage in the Permian "Glossopteris Flora”: a quantitative approach. Review of Palaeobotany and Palynology, 174:113-121. doi:10.1016/j.revpalbo.2012.01.002

Defagó, M.T.; Fenoglio, M.S. \& Salvo, A. 2010. Aspectos biológicos de Lema quadrivittata (Coleoptera: Chrysomelidae), minador de hojas de Commelina erecta en Argentina. Revista Colombiana de Entomología, 36:229-231.

Diaz, I.J. \& Malizzia, D.C. 1983. Estudio geológico y sedimentológico del Terciario Superior del Valle Calchaquí (Dpto. San Carlos, Provincia de Salta). Boletin Sedimentológico, 2:8-21. 
Edwards, P.J \& Wratten, S.D. 1980. Ecology of Insect-Plant Interactions. London. Edward Arnold, 60 p.

Feng, Z.; Su, T.; Yang, J.; Chen, Y.; Wei, H.; Dai, J.; Guo, Y.; Liu, J. \& Ding, J. 2014. Evidence for insect-mediated skeletonization on an extant fern family from the Upper Triassic of China. Geology, 42:407-410. doi:10.1130/G35369.1

Gallego, J.; Cúneo, R.N. \& Escapa, I. 2014. Plant-arthropod interactions in gymnosperm leaves from the Early Permian of Patagonia, Argentina, Geobios, 47:101-110. doi:10.1016/j. geobios.2014.01.002

Gallego, O.F.; Gnaedinger, S.; Kirsten, O. \& Giovanelli, S. 2003. Primera cita de trazas fósiles de insectos en hojas del Pérmico de Uruguay y Triásico de Chile. In: COMUNICACIONES CIENTÍFICAS Y TECNOLÓGICAS, UNIVERSIDAD NACIONAL DEL NORDESTE, 2003. Extended Abstracts, Corrientes, Disponible en: http://www.unne.edu.ar/unnevieja/ Web/cyt/cyt/2003/comunicaciones/06-Biologicas/B-033.pdf; consultado en 29/07/2015.

Galli, C.I.; Anzótegui, L.M.; Horn, M.Y. \& Morton, L.S. 2011. Paleoambiente y Paleocomunidades de la Formación Palo Pintado (Mioceno-Plioceno), Provincia de Salta, Argentina. Revista Mexicana de Geología, 28:161-174.

Galli, C.I.; Ramírez, A.; Barrientos, C.; Reynolds, J.; Viramonte, J.G. \& Idleman, B. 2008. Estudio de proveniencia de los depósitos del Grupo Payogastilla (Mioceno Medio-Superior) aflorantes en el río Calchaquí, provincia de Salta, Argentina. In: CONGRESO GEOLÓGICO ARGENTINO, 17, 2008. Actas, Neuquén, p. 353-354.

García-Robledo, C.; Kuprewicz, E.K. \& Staines, C.L. 2007. Hispine-like herbivore damage in Canna bangii (Zingiberales, Cannaceae) by Anopsilus weevils (Curculionidae, Baridinae). The Coleopterists Bulletin, 61:468-470. doi:10.1649/0010-065X (2007)61[468:HHDICB]2.0.CO;2

García-Robledo, C. \& Staines, C.L. 2008. Herbivory in gingers from Latest Cretaceous to present: is the ichnogenus Cephaloleichnites (Hispinae, Coleoptera) a rolled-leaf beetle? Journal of Paleontology, 82:1035-1037. doi:10.1666/07-089.1

Givulescu, R. 1984. Pathological elements on fossil leaves from Chiuzbaia (galls, mines, and other insect traces). Dari de Seama ale Sedintelor Institutul de Geologie si Geofizica, 68:123-133.

Glasspool, I.; Hilton, J.; Collinson, M. \& Wang, S.J. 2003. Foliar herbivory in Late Palaeozoic Cathaysian gigantopterids. Review of Palaeobotany and Palynology, 127:125-132. doi:10.1016/ S0034-6667(03)00107-6

Grauvogel-Stamm, L. \& Kelber, K.P. 1996. Plant-insect interaction and coevolution during the Triassic in Western Europe. Paleontologica Lombardia, 5:5-23.

Hendrix, S.D. 1977. The resistance of Pteridium aquilinum (L) Kuhn. to insect attack by Trichoplusa ni (Hubn.). Oecologia, 26:347-361.

Hendrix, S.D. 1980. An evolutionary and ecological perspective of the insect fauna of ferns. American Naturalist, 115:171-196.

Hendrix, S.D. \& Marquis, R.J. 1983. Herbivore damage to three tropical ferns. Biotropica, 15:108-111.

Herbst, R. 1977. Sobre Marattiales (Filicopsidae) Triásicas de Argentina y Australia. Parte II. Los generos Danaeopsis y Rienitsia. Ameghiniana, 14:19-32.

Herbst, R.; Anzótegui, L.M.; Esteban, G.L.; Mautino, L.; Morton, L.S. \& Nassif, N. 2000. Síntesis paleontológica del Mioceno de los valles Calchaquíes, noroeste argentino. In: F. Aceñolaza \& R. Herbst (eds.) El Neógeno de Argentina, Instituto Superior de Correlación Geológica, p. 263-288.
Herbst, R.; Anzótegui, L.M. \& Jalfin. L.G. 1987. Estratigrafía, paleoambiente y dos especies de Salvinia Adanson (Filicopsida), del Mioceno superior de Salta, Argentina. Facena, 7:1542.

Hill, C.R. 1987. Jurassic angiosperm (Marattiales) from North Yorkshire. Review of Palaeobotany and Palynology, 81:65-93. doi:10.1016/0034-6667(87)90021-2

Hill, R.S. \& Jordan, G.J. 1998. The fossil record of ferns and fern allies in Australia. In: Flora of Australia, Canberra, CSIRO Publishing, p. 29-36.

Horn, M.Y.; Adami-Rodrigues, K. \& Anzótegui, L.M. 2011. Primeras evidencias de interacción insecto-planta en el Neógeno del Noroeste de la Argentina. Revista Brasileira de Paleontologia, 14:87-92. doi:10.4072/rbp.2011.1.09

Hummel, J.; Gee, C.T.; Südekum, K.H.; Sander, P.M.; Nogge, G. \& Clauss, M. 2008. In vitro digestibility of fern and gymnosperm foliage: implications for sauropod feeding ecology and diet selection. Proceedings of the Royal Society B, 275:1015-1021. doi:10.1098/rspb.2007.1728

Kellogg, D.W. \& Taylor, E.L. 2004. Evidence of oribatid mite detritivory in Antarctica during the late Paleozoic and Mesozoic. Journal of Paleontology, 78:1146-1153. doi:10.1666/00223360(2004)078<1146:EOOMDI>2.0.CO;2

Krassilov, V.A. 2008. Part I: traumas on fossil leaves from the Cretaceous of Israel. In: V.A. Krassilov \& A. Rasnitsyn (eds.) Plant-Arthropod interactions in the Early Angiosperm history, Sophia Moscow and Leiden, p. 8-187.

Krassilov, V.A. \& Shuklina, S. 2008. Arthropod trace diversity on fossil leaves from the mid-Cretaceous of Negev, Israel. Alavesia, 2:239-245.

Labandeira, C.C. 1998. Early history of arthropod and vascular plant associations. Annual Review of Earth and Planetary Sciences, 26:329-377. doi:10.1146/annurev.earth.26.1.329

Labandeira, C.C. 2002a. The history of associations between plants and animals. In: C.M. Herrera \& O. Pellmyr (eds.) Plant-Animal interactions: an evolutionary approach, Blackwell Publishing, p. 26-76.

Labandeira, C.C. 2002b. Paleobiology of middle Eocene plantinsect associations from the Pacific Northwest: A preliminary report. Rocky Mountain Geology, 37:31-59. doi:10.2113/ gsrocky.37.1.31

Labandeira, C.C. 2006. Silurian to Triassic plant and hexapod clades and their associations: new data, a review, and interpretations. Arthropod Systematics \& Phylogeny, 64:53-94.

Labandeira, C.C. \& Allen, E.G. 2007. Minimal insect herbivory for the Lower the Lower Permian coprolite Bon Bed site of northcentral Texas, USA, and comparison to the other Late Paleozoic floras. Palaeogeography, Palaeoclimatology, Palaeoecology, 247:197-219. doi:10.1016/j.palaeo.2006.10.015

Labandeira, C.C. \& Beall, B.S. 1990. Arthropod terrestriality. In: D. Mikulic (ed.) Arthropods: notes for a short course, Short Courses in Paleontology, p. 214-256.

Labandeira, C.C.; Johnson, K.R. \& Lang, P. 2002. Preliminary assessment of insect herbivory across the Cretaceous-Tertiary boundary: major extinction and minimum rebound. In: J.H. Hartman; K.R. Johnson \& D.J. Nichols (eds.) The Hell Creek Formation and the Cretaceous-Tertiary boundary in the Northern Great plains: an integrated continental record of the end of the Cretaceous. Boulder, Geological Society of America, p. 297-327 (Special Paper 361).

Labandeira, C.C. \& Phillips, T.L. 1996a. Insect fluid-feeding on Upper Pennsylvanian tree fern (Paleodictyoptera, Marattiales) and the early history of the piercing-and-sucking functional 
feeding group. Annals of the Entomological Society of America, 89:157-183.

Labandeira, C.C. \& Phillips, T.L. 1996b. A Late Carboniferous petiole gall and the origin of holometabolous insects. Proceedings of the National Academy of Sciences of the United States of America, 93:8470-8474. doi:10.1073/pnas.93.16.8470

Labandeira, C.C. \& Phillips, T.L. 2002. Stem borings and petiole galls from Pennsylvanian tree ferns of Illinois, USA: implications for the origin of the borer and galling functional-feeding-groups and holometabolous insects. Palaeontographica Abteilung A, 264:1-84.

Labandeira, C.C.; Phillips, T.L. \& Norton, R.A. 1997. Oribatid mites and the decomposition of plant tissues in Paleozoic coal-swamp forests. Palaios, 12:319-353. doi:10.2307/3515334

Labandeira, C.C.; Wilf, P.; Johnson, K.R. \& Marsh, F. 2007. Guide to insect (and other) damage types on compressed plant fossils. Washington, Smithsonian Institution, 26 p.

Lesnikowska, A.D. 1990. Evidence of herbivory in tree-fern petioles from the Calhoun Coal (Upper Pennsylvanian) of Illinois. Palaios, 5:76-80. doi:10.2307/3514997

Lowman, M.D. 1984. An assessment of techniques for measuring herbivory: is rain forest defoliation more intense than we thought? Biotropica, 16:264-268. doi:10.2307/2387934

Lowman, M.D. 1985. Insect herbivory in Australian rain forests: is it higher than in the Neotropics? Proceedings of the Ecological Society of Australia, 14:109-19.

Lutz, A.I. \& Martínez, L. 2007. Nuevo género y especie de liana del Mioceno Superior (Formación Palo Pintado), Provincia de Salta, Argentina. Ameghiniana, 44:205-213.

Magalhães, N.; Ferreira, L.B.; Leitão, G. \& Mantovani, A. 2012. Effects of leaf herbivory on the bromeliad Aechmea blanchetiana: a study of selective feeding by the scraper Acentroptera pulchella. Acta Botanica Brasilica, 26:944-952. doi:10.1590/S0102-33062012000400024

McLoughlin, S.; Martin, S.K. \& Beattie, R. 2015. The record of Australian Jurassic plant-arthropod interactions. Gondwana Research, 27:940-959. doi:10.1016/j.gr.2013.11.009

Mehltreter, K. 2010. Interactions of ferns with fungi and animals. In: K. Mehltreter; L.R. Walker \& J.M. Sharpe (eds.) Fern ecology, Cambridge University Press, p. 220-254.

Mehltreter, K.; Hülber, K. \& Hietz, P. 2006. Herbivory on epiphytic ferns of a Mexican cloud forest. Fern Gazette, 17:303-309.

Mehltreter, K. \& Tolome, J. 2003. Herbivory on three tropical fern species of a Mexican cloud forest. In: S. Chandra \& M. Srivastava (eds.) Pteridology in the new millennium, Kluwer Academic Publishers, p. 375-381. doi:10.1007/978-94-0172811-9_26

Niklas, K.J.; Tiffney, B.H. \& Knoll, A.H. 1983. Patterns in vascular land plant diversification. Nature, 303:614-616. doi:10.1038/303614a0

Patra, B. \& Bera, S. 2007. Herbivore damage to ferns caused by a chrysomelid beetle from Lower Gangetic Plains of West Bengal, India. American Fern Journal, 97:19-29. doi:10.1640/00028444(2007)97[19:HDTFCB]2.0.CO;2

Ponomarenko, A.G. 2002. Superorder Scarabaeidea Laicharting, 1781. Order Coleoptera Linné, 1758. The Beetles. In: A.P. Rasnitsyn \& D.L.J. Quicke (eds.) History of insects, Kluwer Academic Publisher, p 164-176.

Prevec, R.; Labandeira, C.C.; Neveling, J.; Gastaldo, R.A.; Looy, C. \& Bamford, M. 2009. A portrait of a Gondwanan ecosystem: a new Late Permian locality from KwaZulu-Natal, South Africa. Review of Palaeobotany and Palynology, 156:454-493. doi:10.1016/j.revpalbo.2009.04.012
Rex, G.M. \& Galtier, J. 1986. Sur l'evidence d'interactions animalvegetal dans le Carbonifere inferieur francais. Comptes Rendus de l'Academie des Sciences, 303:1623-1626.

Rößler, R. 2000. The late Palaeozoic tree fern Psaronius - an ecosystem unto itself. Review of Palaeobotany and Palynology, 108:55-74. doi:10.1016/S0034-6667(99)00033-0

Rößler, R. 2001. Medullosa - sonderbare Samenpflanze mit Farnwedeln. In: R. Rößler (ed.) Der versteinerte Wald von Chemnitz, Naturkundemuseum Chemnitz, p. 112-123.

Rothwell, G.W. 1987. Complex Paleozoic Filicales in the evolutionary radiation of ferns. American Journal of Botany, 74:458-461. doi:10.2307/2443822

Rothwell, G.W. \& Scott, A.C. 1983. Coprolites within marattiaceous fern stems (Psaronius magnificus) from the Upper Pennsylvanian of the Appalachian Basin, U.S.A. Palaeogeography, Palaeoclimatology. Palaeoecology, 41:227232. doi:10.1016/0031-0182(83)90089-5

Rothwell, G.W. \& Stockey, R.A. 1989. Fossil Ophioglossales in the Paleocene of western North America. American Journal of Botany, 76:637-644. doi:10.2307/2444411

Rothwell, G.W. \& Stockey, R.A. 2008. Phylogeny and evolution of ferns: a paleontological perspective. In: T.A. Ranker \& C.H. Haufler (eds.) Biology and evolution of ferns and Lycophytes, Cambridge University Press, p. 332-366.

Rowell, C.H.F.; Rowell-Rahier, M.; Braker, H.E.; Cooper-Driver, G.A. \& Gomez, P.L.D. 1983. The palatability of ferns and the ecology of two tropical forest grasshoppers. Biotropica, 15:207216. doi:10.2307/2387830

Santiago-Blay, J.A. 1994. Paleontology of leaf beetles. In: P. Jolivet; M.L. Cox \& E. Petitpierre (eds.) Novel aspects of the biology of Chrysomelidae, Springer, p. 1-68. doi:10.1007/97894-011-1781-4_1

Sarzetti, L.C. 2010. Análisis icnológico de las asociaciones planta insecto de la tafoflora de Río Pichileufú (Eoceno Medio, Río Negro). Facultad de Ciencias Naturales e Instituto Miguel Lillo, Universidad Nacional de Tucumán, $\mathrm{PhD}$ thesis, 345 p. (Unpublished)

Sarzetti, L.C.; Labandeira, C.C. \& Genise, J.F. 2008. A leafcutter bee trace fossil from the middle Eocene of Patagonia, Argentina and a review of megachilid (Hymenoptera) ichnology. Palaeontology, 51:933-941. doi:10.1111/j.1475-4983.2008.00787.x

Sarzetti, L.C.; Labandeira, C.C.; Wilf, P.; Muzón, J.; Cúneo, R.N.; Johnson, K.R. \& Genise, J.F. 2009. Odonatan endophytic oviposition from the Eocene of Patagonia: the ichnogenus Paleoovoidus and implications for behavioral stasis. Journal of Paleontology, 83:431-447. doi:10.1666/08-121.1

Scheckler, S.E. 1974. Systematic characters of Devonian ferns. Annals of the Missouri Botanical Garden, 61:462-473. doi:10.2307/2395068

Schuettpelz, E. \& Pryer, K.M. 2009. Evidence for a Cenozoic radiation of ferns in an angiosperm-dominated canopy. Proceedings of the National Academy of Sciences of the United States of America, 106:11200-11205. doi:10.1073/pnas.0811136106

Scott, A.C.; Chaloner, W.G. \& Paterson, S. 1985. Evidence of pteridophyte-arthropod interactions in the fossil record. Proceedings of the Royal Society of Edinburgh, 86:133-140. doi:10.1017/S0269727000008058

Scott, A.C. \& Paterson, S. 1984. Techniques for the study of plant/ arthropod interactions in the fossil record. Geobios, 8:449-455. doi:10.1016/S0016-6995(84)80203-X

Scott, A.C.; Stephenson, J. \& Chaloner, W.G. 1992. Interaction and coevolution of plants and arthropods during the Palaeozoic and Mesozoic. Philosophical Transactions of the Royal Society of London B, 335:129-165. doi:10.1098/rstb.1992.0016 
Scott, A.C. \& Taylor, T.N. 1983. Plant/animal interactions during the Upper Carboniferous. Botanical Review, 49:259-307. doi:10.1007/BF02861089

Seward, A.C. 1923. The use of the microscope in palaeobotanical research. Journal of the Royal Microscopy Society, 43:299-302. doi:10.1111/j.1365-2818.1923.tb05176.x

Seward, A.C. 1924. On a new species of Tempskya from Montana: Tempskya knowltoni, sp. nov. Annals of Botany, 38:485-507.

Slater, B.J.; McLoughlin, S. \& Hilton, J. 2012. Animal-plant interactions in a Middle Permian permineralised peat of the Bainmedart Coal Measures, Prince Charles Mountains, Antarctica. Palaeogeography, Palaeoclimatology, Palaeoecology, 363-364:109-126. doi:10.1016/j.palaeo.2012.08.018

Soo Hoo, C.F. \& Fraenkel, G. 1964. The resistance of ferns to the feeding of Prodenia eridania larvae. Annals of the Entomological Society of America, 57:788-90.

Srivastava, A.K. \& Agnihotri, D. 2011. Insect traces on Early Permian plants of India. Paleontological Journal, 45:200-206. doi:10.1134/S0031030111020171

Stephenson, J. \& Scott, A.C. 1992. The geological history of insect-related plant damage. Terra Nova, 4:542-552. doi:10.1111/j.1365-3121.1992.tb00596.x

Straus, A. 1977. Gallen, Minen und andere Fraßspuren im Pliokän von Willershauen am Harz. Verhandlungen des Botanischen Vereins der Provinz Brandenburg, 113:43-80.

Strong, D.R. 1977. Rolled-leaf hispine beetles (Chrysomelidae) and their Zingiberales host plants in Middle America. Biotropica, 9:156-169. doi:10.2307/2387878

Strong, D.R.; Lawton, J.H. \& Southwood, R. 1984. Insects on plants. Cambridge, Harvard University Press, 320 p.

Swain, T. \& Cooper-Driver, G.A. 1973. Biochemical systematics in the Filicopsida. Botanical Journal of the Linnean Sociey, 1:111-134.

Tahvanainen, J. \& Niemelä, P. 1987. Biogeographical and evolutionary aspects of insect herbivory. Annales Zoologici Fennici, 24:239-247.

Taylor, T.N.; Taylor, E.L. \& Krings, M. 2009. Paleobotany. The biology and evolution of fossil plants. London, Elsevier/ Academic Press Inc., 1230 p.

Tidwell, W.D. \& Ash, S.R. 1994. A review of selected Triassic to Early Cretaceous ferns. Journal of Plant Research, 107:417-442. doi:10.1007/BF02344066

Tidwell, W.D. \& Hebbert, N. 1992. Species of the Cretaceous tree fern Tempskya from Utah. International Journal of Plant Sciences, 153:513-528.

Tomescu, A.M.F.; Rothwell, G.W. \& Trivett, M.L. 2006. Kaplanopteridaceae fam. nov., additional diversity in the initial radiation of filicalean ferns. International Journal of Plant Sciences, 167:615-630. doi:10.1086/500998

Trout, M.K.; Labandeira, C.C. \& Chapman, R.E. 2000. A morphometric analysis of insect damage on Neuropteris and implications for Paleozoic herbivory. Abstracts with Programs, Geological Society of America, 32:219-220.

Tryon, A.F. 1985. Spores of myrmecophytic ferns. Proceedings of the Royal Society of Edinburgh, 86B:105-110. doi:10.1017/ S0269727000008010
Van Amerom, H.W.J. 1966. Phagophytichnus ekowski nov. ichnogen. \& nov. ichnosp., eine Missbildung infolge von Insektenfrass, aus dem spanischen Stephanien (Provinz Leon). Leidse Geologische Mededelingen, 38:181-184.

Van Konijnenburg-Van Cittert, J.H.A. 1989. Dicksoniaceous spores in situ from the Jurassic of Yorkshire, England. Review of Palaeobotany and Palynology, 61:273-301. doi:10.1016/00346667(89)90035-3

Vasilenko, D.V. 2005. Damages on Mesozoic plants from the Transbaikalian locality Chernovskie Kopi. Paleontological Journal, 39:54-59.

Vasilenko, D.V. 2007a. Feeding damage on upper Permian plants from the Sukhona River. Paleontological Journal, 41:207-211. doi:10.1134/S0031030107020116

Vasilenko, D.V. 2007b. Evidence of terrestrial arthropod and plant interaction from the Upper Mesozoic of Asia. Moscow State Forest University, PhD thesis, 140 p. (Unpublished) [In Russian].

Vialov, O.S. 1975. The fossil traces of nourishment of the insect. Collections of Paleontological Papers, 12:147-155 [In Russian].

Wang, Y. 1999. Fertile organs and in situ spores of Marattia asiatica (Kawasaki) Harris (Marattiales) from the Lower Jurassic Hsiangchi Formation in Hubei, China. Review of Palaeobotany and Palynology, 107:125-144. doi:10.1016/ S0034-6667(99)00025-1

Wappler, T. 2010. Insect herbivory close to the OligoceneMiocene transition - a quantitative analysis. Palaeogeography, Palaeoclimatology, Palaeoecology, 292:540-550. doi:10.1016/j. palaeo.2010.04.029

Wappler, T. \& Denk, T. 2011. Herbivory in early Tertiary Arctic forests. Palaeogeography, Palaeoclimatology, Palaeoecology, 310:283-295. doi:10.1016/j.palaeo.2011.07.020

Webb, J. 1982. Triassic species of Dictyophyllum from Eastern Australia. Alcheringa, 6:79-91. doi:10.1080/03115518208566988

Wilf, P.; Labandeira, C.C.; Johnson, K. \& Cuneo, R.N. 2005. Richness of plant-insect associations in Eocene Patagonia: a legacy for South American biodiversity. Proceedings of the National Academy of Sciences of the United States of America, 25:8944-8948. doi:10.1073/pnas.0500516102

Wilf, P.; Labandeira, C.C.; Kress, W.J.; Staines, C.L.; Windsor, D.M.; Allen, A.L. \& Johnson, K. 2000. Timing the radiations of the leaf beetles: hispines on gingers from Latest Cretaceous to Recent. Science, 289:291-294. doi:10.1126/science.289.5477.291

Williams-Linera, G. \& Baltazar, A. 2001. Herbivory on young and mature leaves of one temperate deciduous and two tropical evergreen trees in the understory and canopy of a Mexican cloud forest. Selbyana, 22:213-18.

Zherikhin, V.V. 2002. Ecological history of the terrestrial insects. In: A.P. Rasnitsyn \& D.L.J. Quicke (eds.) History of insects, Kluwer Academic Publisher, p. 303-324.

Zwölfer, H. 1978. Mechanismen und Ergebnisse der Co-Evolution von phytophagen und entomophagen Insekten und höheren Pflanzen. Sonderband Naturwissenscaften Verein im Hamburg, 2:7-50.

Received in September, 2014; accepted in June, 2015. 